\title{
Research on factors contributing to the development of accommodation facilities in areas with environmental constraints
}

\author{
Lyudmila Maksanova $^{1 *}$, Alyona Andreeva ${ }^{1}$, Ivan Kaurov$^{1}$, and Darima Budaeva ${ }^{1}$ \\ ${ }^{1}$ Baikal Institute of Nature Management, Siberian Branch of the Russian Academy of Sciences, \\ 670047, 6 Sakhyanovoy str., Ulan-Ude, Buryatia, Russian Federation
}

\begin{abstract}
Recently studies of factors affecting the successful operation of small-scale accommodation facilities have expanded significantly. Mandatory classification of hotels and other accommodation facilities is one of the key factors to increase their competitiveness. However, there are few works studying the problems of classifying small-scale accommodation facilities in conditions of infrastructural restrictions in environmentally sensitive areas. Therefore, the factors affecting the functioning of smallscale accommodation facilities in territories with environmental restrictions are discussed in this study in the context of the mandatory classification of hotels and other accommodation facilities in the Russia. The research uses the case of Enkheluk village's guest houses (Russian Federation, Republic of Buryatia). Primary data obtained during the interviews with local entrepreneurs in 2018 was used in the study. The main infrastructural restrictions influencing the entrepreneurs providing temporary tourists' accommodation were revealed: in the field of water supply, wastewater disposal, passing an environmental assessment. These problems, having a dynamic and interconnected nature, constrain the passing of mandatory classification by small-scale accommodation facilities. Possible ways of solving these problems are formulated. The study's results can serve as the basis for further studies of factors affecting entrepreneurial and investment activities in the field of accommodation in environmentally sensitive areas.
\end{abstract}

\section{Introduction}

Worldwide, the development of tourism in rural areas is characterized by the growth of a small hotel business [1-2], which provides personalized services on a small scale [3]. The changes in behavior of tourism industry customers and the search for new products [4] have affected the appearance of many types of small-scale accommodations such as a bed and breakfast (B\&B), a guest house, a farm stay, a boarding house, a lodging house and a selfcatering facility [5]. Researchers pay special attention to the study of factors that contribute to the success of guest houses. Some researchers identify factors such as home atmosphere, room facilities, other facilities, service, cleanliness, location, and value for money [5]. Highquality infrastructure that ensures work of small enterprises offering accommodation services

\footnotetext{
*Corresponding author: 1maksanova@yandex.ru
} 
is essential to their sustainable development. The local environment in which the enterprise operates may affect its productivity or survival to a greater extent than for other enterprises [6]. Scholar Benjamin Bassey believes that the tourism industry is unlikely to flourish even in those territories that are rich in natural and cultural resources without providing these territories with a high-quality tourism infrastructure, developing business communities, designing a tourism product, and promoting territories [7].

When visiting Lake Baikal, one of the most popular tourist symbols of Russia, the smallscale accommodation section plays a key role in tourism product design. Lake Baikal is one of the most ancient freshwater reservoirs of the planet, a unique ecological system of Russia and a UNESCO world heritage site. It is well known that World Heritage Sites have a greater tourist enhancing effect [8] and, at the same time, they can act as a win-win guarantee of sustainable environmental protection because of the direct interest tourist products' producers, locals and authorities in the preservation of tourism income [9].

According to the Ministry of Natural Resources of the Russian Federation from 2007 to 2017, the number of tourists visiting Lake Baikal increased by three-and-a-half times and totaled over 260 thousand tourists in 2017. The increased demand for the Baikal tourism product has led to the rapid entrepreneurship growth, followed by the involvement of local residents in tourism services by constructing guest houses. Such approach was prescribed by the national priority of stimulating business initiatives in rural communities [10].

Over the past two decades with the purpose of the sustainable tourism development in Lake Baikal basin the government has made decisions to develop special economic areas of tourist-recreational type, tourism business clusters, which marked the prerequisites for a modern tourism infrastructure construction [11]. However, it is worth mentioning that despite the priority status of tourism and the actions taken by the government to support it, the problem of infrastructure provision hinders construction of guest houses. Many of them are forced to use individual or self-contained units for cold and hot water supply and sewerage against the backdrop of low development of centralized infrastructure. Thus, given hard limits on economic and other businesses set by the Federal Lake Baikal Protection Act, it raises major concerns in future activities of small-scale accommodation facilities, as there is growing concernment about passing the mandatory classification [12]. Since 2019 this problem has become the matter of discussion on the part of local authorities, scientists, business owners and the public, when a phased hotel classification began in Russia. [13]

This article analyzes factors affecting the development of small-scale accommodation facilities in the context of their mandatory classification under infrastructural restrictions in the central ecological zone of Baikal Natural Area. The study was conducted through the example of Enkheluk village, which is a popular tourist destination in the Baikal region [14]. The destination is located on the coast of Lake Baikal in Kabansky district, $170 \mathrm{~km}$ from the Ulan-Ude, capital of the Republic of Buryatia (fig. 1). It gets over 5\% of the tourist flow in the Republic of Buryatia, which amounted to 1106 thousand tourists in 2018.

As the information base of this study we used legislative, regulatory documents in the sphere of protection of Lake Baikal and tourism development; cartographic and archive materials of Baikal Institute of Nature Management, Siberian Branch of the Russian Academy of Sciences, public informational and analytical materials. Also as the information base of the study we used the results of field surveys and interviews with entrepreneurs. Meetings and interviews with all owners and managers of guest houses in Enkheluk village were organized during the study in 2018. Entrepreneurs were asked to describe the problems which arise organizing business activity for placing tourists in the central ecological zone of the Baikal Natural Area. 


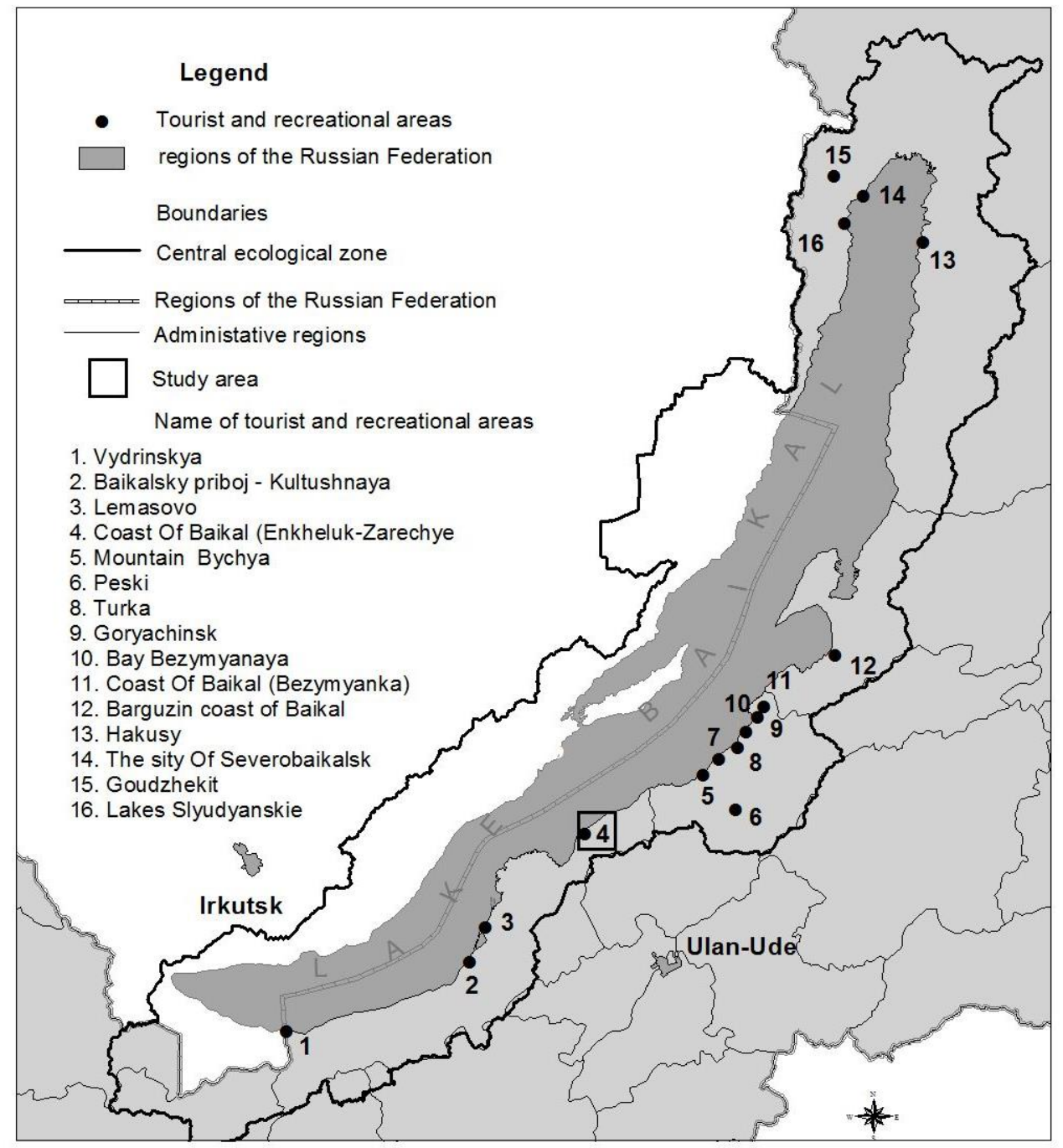

Figure 1. The location of Enkheluk village in the central ecological zone of Baikal Natural Area

\section{Results and Discussion}

In the last decade, the mandatory classification of hotels and other accommodation facilities is one of the important topics. And this subject is actively studied by the Russian scientists due to the increased need for the development of tourism and tourist infrastructure $[12,13$, 15]. All over the world, classification of hotels and other accommodation facilities is considered as efficient way to ensure the proper level for high-quality and safety of the services they provide [16]. The classification of hotels and other accommodation facilities is understood as a division into certain categories, which is carried out on the basis of assessing the conformity of hotels and other accommodation facilities, also the hotel services provided in them with the requirements established by the Regulation on Hotel Classification (approved by Resolution of the Government of the Russian Federation No. 158 dated 16.02.2019). 
The phased mandatory classification of hotels and other accommodation facilities in Russia began in 2019. And all this campaign should be finalized by 2021. The country already has successfully tested and implemented the experience of mandatory hotels' and other accommodation facilities' classification in the Olympic Sochi (2014) and in the host cities of the World Cup (2018). However, despite of the possession of rather effectively realized examples, which have listed above, concern about passing the procedure of smallscale accommodation facilities' classification is growing, especially regarding located in the countryside. It should be noted that such objects include a «rural guest house». It's understood as a small-scale specialized accommodation facility (often family-owned) which provides his guests temporary accommodation services and additional services such as organizing leisure, meals, excursions and others.

In total, the Russian hotel classification system include of 6 categories: «five stars», «four stars», «three stars», «two stars», «one star», «without stars». There is specific set of requirements for each category depending on the type of accommodation. Small-scale accommodation facilities usually prefer the lowest of the categories - «no stars». The minimum list of requirements for facilities of this category provides next: technical equipment ensuring round-the-clock hot and cold water supply; heating with air temperature in residential premises not lower than +21.5 degrees Celsius and in public areas not lower than +18.5 degrees Celsius; ventilation system (natural and/or forced); sewage system; television, telephone and Internet in public areas.

Problems with passing mandatory hotels' and other accommodation facilities' classification are especially acute in the regions located beyond the Urals and in the Far North' regions due to a significant discrepancy with established requirements and low infrastructure development [17]. Major challenges for small-scale accommodation facilities may arise with the preparation of documents' set related to fire safety, compliance of sanitary and hygienic conditions, anti-epidemic norms and rules, also environmental protection requirements. These very fears are fully manifested in the Baikal Natural Area, where the lack of high-quality utilities for hotels and other accommodation facilities located near the lake Baikal contributes to increase in the cost of their classification. It leads to increase the cost of their services and therefore decrease their attractiveness for tourists.

In Baikal Natural Area, the business model for providing temporary accommodation for tourists is based on the idea of using private households located on land intended for private housing construction, in the format of building guesthouses. Now 16 tourist accommodation facilities in Enkheluk village have a capacity of 903 beds. A guest house is the main type of accommodation. Rural guesthouses may include mini-hotels, agritourism farms, angler and hunter houses, houses, bungalows and other small-scale accommodation facilities. According to the National Standard, a guesthouse is a small-scale accommodation facility (most commonly for families), providing temporary accommodation services for guests, as well as additional meal, excursion and leisure services. The minimum capacity of a guesthouse in Enkheluk village is 12 beds (the maximum is 50). Most commonly, the owners of the guesthouses are local people, business people who own land and buildings, as well as people who buy property as summerhouses. 7 tourist accommodation facilities (with a capacity of 241 beds) operate all year round, the rest are closed for conservation to reduce maintenance costs in winter and off-season period (from October to May).

The Podlemorye travel cluster project, launched in 2012 with federal support, has initiated changes that have shaped the modern architectural, economic, social and ecological landscape of Enkheluk village over the past decade. This example of tourist destination demonstrates effective ways of reviving a rural area with the current population of 172 people.

The tourist accommodation facilities provide the local people with jobs, as well as consume products and services that are produced in the area, leading to a multiplier effect. It 
is worth noting that the approach of reviving traditional villages through rural tourism is widespread in the world [18].

In the absence of centralized engineering support facilities, individual or self-contained units for cold and hot water supply and sewerage are used in the operation of guesthouses. However, even if there is a substantial evidence of an appropriate environmental policy implementation, the results of a large-scale inspection of accommodation facilities in Baikal Natural Area showed that more than $90 \%$ of them operate in violation of the current legislation requirements [19]. According to the study, the main problems faced by the business model of guest houses, and as a result of which this model has become vulnerable when passing the mandatory hotel classification reside in land utilization, water supply, sewerage and ecological assessment.

Land resources are a key factor that influences the development of accommodation facilities. The territory of tourist destination Enkheluk is small and bordered by forestry lands, which conversion to settlement lands is prohibited (according to Article 11 of the Federal Law of Russia No. 94-FZ dated 01.05.1999 «On the Protection of Lake Baikal». The scarcity of land resources complicates the allocation of lands for investment projects that results in creation of accommodation facilities on the lands allocated for individual housing construction. To conduct a business, the owners of guest houses need to change the type of permitted use of a land plot according to Order of the Ministry of Economic Development of Russia No. 540 dated 01.09.2014 «On approval of the classifier of the types of permitted use of land plots». This procedure may have certain economic consequences for entrepreneurs:

1) in case of misusing of land plot-payment of a fine;

2) in case of changing of type of permitted use of a land plot for business purposesincrease in land tax rate from $0.3 \%$ to $1.5 \%$.

3) furthermore, lengthy period of processing of documents (up to 6 months) leads to the loss of profits caused by the temporary discontinuation of activities during that time.

A change of type of permitted use of a land plot for business purposes in turn leads to a change of real estate' land purpose, intended for tourist accommodation (where collective accommodation facilities must be non-living premises, according to legislation).

Registration of a real estate item is another factor that significantly affects the classification process of accommodation facilities. Registration of ownership for buildings includes the following procedures:

1) obtaining construction permits and a commissioning certificate of all buildings and structures;

2) endorsement of the public ecological assessment on a design documentation during the construction or reconstruction of facilities;

3) submitting documents to Federal Service for State Registration, Cadastre and Cartography and paying of state duty.

These actions are associated with significant expenses. In addition, the property tax rate will increase significantly as a result of changes in the cadastral value and the tax rate. Considering overall costs, coming from bureaucratic procedures and documents processing, not many owners of guest houses would wish change type of permitted use of a land plot and designation of a real estate. Finally, it can lead to a complete cessation of business activity related to a guest house. We should note, that the legislation allows dividing of individual housing construction land plot into two parts, one of which receives a type of permitted use - «private enterprise». However, as we noted earlier, the area of land is too small, that makes impossible the compliance with sanitary and epidemiological requirements for drinking water, drinking and household water supply. This is another significant factor that has an impact on guest house businesses.

In accordance with the hotel classification procedure, the applicant must provide a copy of conformity statement that the water used for drinking meets the requirements of sanitary 
and epidemiological rules and standards. There is no centralized water supply in Enkheluk destination. Each guest house has a well. If type of permitted use of a land plot changes, a well can be used only with a sanitary protection zone (SPZ), according the sanitary and epidemiological rules. In order to construct only the first half of a protective sanitary zone, a circumference with an area of at least 28.3 ar is required without any residential and household buildings. In addition, there will be certain expenses for the project development and its approval for constructing a well in the protective sanitary zone by the consumer protection and human well-being authority. Taking into account small land areas of guest houses and absence of free space, it seems to be impossible to meet the requirements for SPZ operation. In our opinion, in these conditions, the construction of water intake facilities is required, according to the plan for development of the Podlemorye travel cluster.

Water disposal in Enkheluk village is of great challenge. The legislation on the protection of Lake Baikal bans in the central ecological zone of BNT:

1) to exploit accommodation facilities without installations for wastewater treatment in accordance with approved standards;

2) to discharge wastewater without treatment up to required effluent quality.

Meanwhile, there are no treatment facilities in the destination. About half of the accommodation facilities use local waste treatment installations with deep biological treatment for domestic wastewater disposal. Small-scale accommodation facilities use cesspools, waste pits. In both cases, it is necessary to ensure the removal of liquid household waste to existing purification facilities that are located outside Baikal Natural Area, $110 \mathrm{~km}$ away from the destination. For those entrepreneurs who use local purification plants, despite the high degree of treatment, there is a ban on dumping waste waters without treatment to the standard quality. In such conditions, compliance with the classification requirements for a technical equipment providing sewage drainage will lead to highly increased costs for entrepreneurs, and consequently, to increased costs of provided services. According to the authors' opinions, it is necessary to initiate measures of government support for entrepreneurs during the construction of purification facilities in the tourism and recreational cluster «Podlemorye», which currently seems a difficult task due to the lack of a suitable land plot. Thus, in order to develop tourism in the region, it is advisable to settle land issues, the solution of which in Baikal Natural Area is possible by transferring forest lands into settlements.

\section{Conclusion}

As part of the study, it was discovered that business activities for providing temporary tourism accommodation are extremely vulnerable due to imperfect legislation, lack of or imperfection of the engineering support system (cold and hot water supply, water drainage, heat supply, and electricity) in Baikal Natural Area. Infrastructure restrictions, which have dynamic and interconnected nature, are not only a deterrent for guest houses to pass the mandatory classification, but also affect the local community's interests in the development of rural areas.

It should be noted if guest houses on Lake Baikal have to forced terminate the legal business activity of due to difficulties in undergoing the mandatory classification procedure, several negative consequences will be expected. Firstly, part of the guest houses in Enkheluk village will go «into the shadows». So this not only lead to the reducing tax and non-tax revenues to budgets at all levels, but also lead to the complicating the control of their economic activities, not to mention the environmental consequences. Secondly, the total capacity of the guest houses in Enkheluk village will significantly decrease, and the emerging demand will be implemented by various forms of tourism organization, including camping, glamping, etc. This would necessarily mean increased environmental burden. The share of unorganized flow in the destination may grow by $60 \%$. 
According to the authors, given the restrictions set by the current Russian legislation requirements, the classification of small-scale accommodation facilities seems to be difficult to accomplish without improving the legal and administrative regulation of natural resource use in Baikal Natural Area, solving infrastructure problems, state support for tourism activities, as well as forming ecological responsibility for both consumers and producers of tourism products, public agencies and local population.

Taking into account the very limited number of scientific studies devoted to the development of small-scale accommodation facilities under infrastructural constraints, the results of this work can serve as the basis for further studies of factors which affecting entrepreneurial and investment activities to the field of accommodation in environmentally sensitive areas.

The article was prepared as part of the state task AAAA-A 17-117102740107-7.

\section{References}

1. Y. Shun, H.Xiao, L. Zhou, Int. J. Hosp. Manage., 76, 29-38 (2019)

2. L.C. Chen, S.P. Lin, C.M. Kuo, Int. J. Hosp. Manage., 32, 278-286 (2013)

3. Y. Hsieh, Y. Lin, Int. J. Hosp. Manage., 29, 576-581 (2010)

4. I. Albaladejo-Pina, M. Díaz-Delfa, Tourism Manage., 30, 805-811 (2009)

5. S.Wang, K. Hung, Int. J. Hosp. Manage., 48, 92-101 (2015)

6. M. Falka, E. Hagstenb, Tourism Manage., 68, 401-411 (2018)

7. B. E. Bassey, Afr. J. Bus. Manage., 9 (15), 569-580 (2015)

8. C.-H. Yang, H.-L. Lin, C.-C. Han, Tourism Manage., 31, 827-837 (2010)

9. S.M. Farid, Procedia - Social and Behavioral Sciences, 211, 595-604 (2015)

10. A. V. Trukhachev, Services in Russia and abroad, 1 (62), 64-84 (2016)

11. O. V. Evstropyeva, Geography and Natural Resources, 5, 184-195 (2016)

12. R. M. Arseniy, Services in Russia and abroad, 4 (82), 75-83 (2018)

13. G. A. Karpova, L. V. Khoreva, Izvestiâ Sankt-Peterburgskogo gosudarstvennogo èkonomičeskogo universiteta, 2 (74), 66-71 (2012)

14. A. K. Tulokhonov, L. B.-Zh. Maksanova, D. G. Budaeva, I. S. Karnaukh, Proc. Int. Conf. Environmental Science for Construction Industry, MATEC Web of Conferences, 193, 05018 (2018)

15. T.V. Efimtseva, Actual Problems of the Russian Law, 11 (96), 26-31 (2018)

16. A.A. Korneev, M.Y.Rudneva, A.M. Shiyanova, Services in Russia and abroad, 2 (63), 164-172 (2016)

17. T.I.Kubassova, A.S.Romanova, Proc. IV All-Russian Scientific and Practical Conf. Activation of Intellectual and Resource Potential of Regions, 77-82 (2018)

18. J. Gao, B. Wu, Tourism Manage., 63, 223-233 (2017)

19. L. B.-Zh. Maksanova, A. M. Andreeva, I. A. Kaurov, D. G. Budaeva, Tourism: Law and Economy, 1 (2020) (to be published) 